\author{
Marquette University \\ e-Publications@Marquette
}

8-2005

\title{
A short synthesis of the common dihydropyran segment of the antifungal agents ambruticin and jerangolid $A$
}

Julie Lukesh

Marquette University

William Donaldson

Marquette University, william.donaldson@marquette.edu

Follow this and additional works at: https://epublications.marquette.edu/chem_fac

Part of the Chemistry Commons

\section{Recommended Citation}

Lukesh, Julie and Donaldson, William, "A short synthesis of the common dihydropyran segment of the antifungal agents ambruticin and jerangolid A" (2005). Chemistry Faculty Research and Publications. 58.

https://epublications.marquette.edu/chem_fac/58 
Marquette University

e-Publications@Marquette

\section{Chemistry Faculty Research and Publications/College of Arts and Sciences}

This paper is NOT THE PUBLISHED VERSION; but the author's final, peer-reviewed manuscript. The published version may be accessed by following the link in the citation below.

Tetrahedron Letters, Vol. 46, No. 33 (August 15, 2005): 5529-5531. DOl. This article is (C) Elsevier and permission has been granted for this version to appear in e-Publications@Marquette. Elsevier does not grant permission for this article to be further copied/distributed or hosted elsewhere without the express permission from Elsevier.

\section{A Short Synthesis of The Common Dihydropyran Segment of The Antifungal Agents Ambruticin and Jerangolid A}

Julie M. Lukesh

Department of Chemistry, Marquette University, Milwaukee, WI William A. Donaldson

Department of Chemistry, Marquette University, Milwaukee, WI

\section{Abstract}

The dihydropyranyl segment common to ambruticin and jerangolid A was prepared in six steps (31.7\% yield) from (S)-2-benzyloxypropanal via silyloxydiene cyclocondensation, followed by C-glycosidation, and eventual epimerization at C18.

\section{Graphical abstract}

The title segment was prepared in six steps, 31.7\% yield from (S)-2-benzyloxypropanal. 


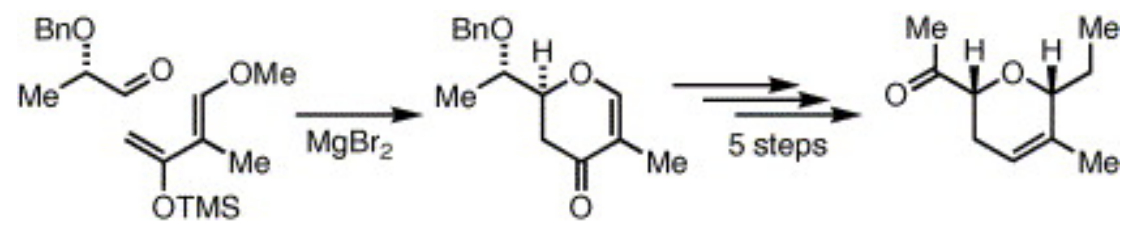

\section{Keywords}

Hetero-Diels-Alder cycloaddition, C-glycosidation

Ambruticin (1, Scheme 1) is a structurally unique carboxylic acid isolated from Polyangium cellulosum var. fulvum, which exhibits potent oral antifungal activity against Coccidioides immitis, Histoplasma capsulatum and Blastomyces dermititidis. ${ }^{1}$ Extensive spectral analysis revealed that the structure of $\mathbf{1}$ consists of a tetrahydropyranyl ring, a dihydropyranyl ring and a divinylcyclopropane ring. More recently, the jerangolids $A$ and $D(\mathbf{2 a}, \mathbf{b})$, isolated from a strain of Sorangium cellulosum (So ce 307 ), were found to exhibit antifungal activity similar to that of $1 .^{2}$ The structure of 2 from C6-C18 is identical with the C13-C24 segment of ambruticin, and similar antibiotic spectrum of $\mathbf{1}$ and $\mathbf{2}$ suggests that these segments are responsible for their biological activity. The complex array of diverse functionality present in $\mathbf{1}$ has generated considerable synthetic interest, ${ }^{3}$ including total syntheses by the groups of Kende et al., ${ }^{4}$ Martin and co-workers, ${ }^{5}$ Lee et al. ${ }^{6}$ and Liu and Jacobsen. ${ }^{7}$ To our knowledge, there are no reported syntheses of the jerangolids. As part of our interest in the preparation of $C$ glycosides, ${ }^{8}$ we herein report the enantioselective preparation of the common dihydropyranyl segment 3 , an intermediate in the Martin synthesis of $1 .^{5}$

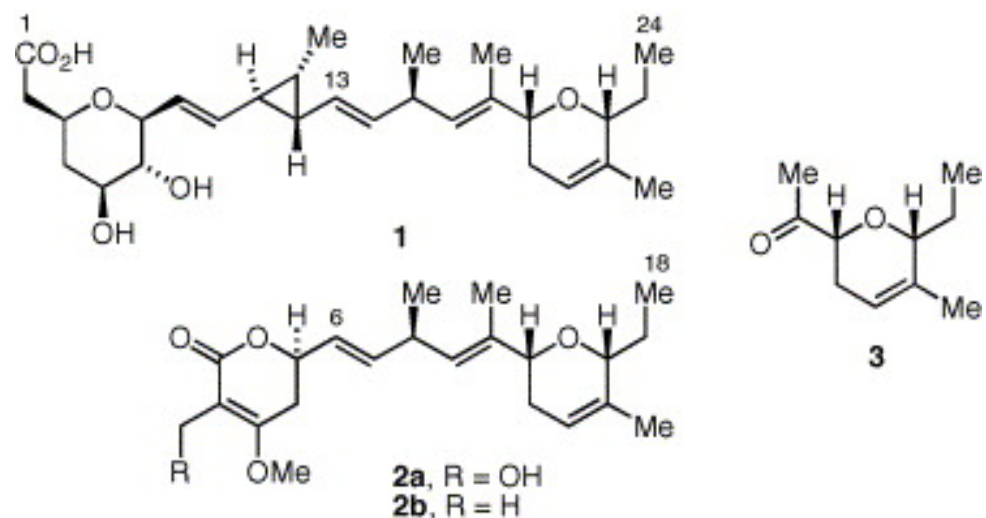

Scheme 1.

Construction and elaboration of the oxane ring was envisioned by means of a Lewis acid catalyzed dienealdehyde cyclocondensation reaction, ${ }^{9}$ followed by a C-glycosidation of the derived pseudoglycal. Since Cglycosidation generally proceeds via axial attack on an oxonium ion to afford trans-2,6-disubstituted pyrans, it was anticipated that a subsequent epimerization at C18 (ambruticin numbering) would be necessary to generate the desired cis-18,22 relative stereochemistry. To this end, reaction of $2(S)$-benzyloxypropanal $(4)^{10}$ with 1methoxy-2-methyl-3-(trimethylsiloxy)-1,3-butadiene $(\mathbf{5})^{11}$ in the presence of $\mathrm{BF}_{3}$-etherate, followed by work-up with TFA gave an inseparable mixture of diastereomeric dihydropyrones $\mathbf{6}$ and $\mathbf{7}$ (Scheme 2). The relative stereochemistry of 6 and $\mathbf{7}$ was assigned on the basis of their ${ }^{1} \mathrm{H}$ NMR spectral data. ${ }^{12}$ In particular, the signals for $\mathrm{H} 17$ and $\mathrm{H}_{1} 9_{\text {eq }}$ (ambruticin numbering) of 6 ( $\delta 3.69$ and $2.36 \mathrm{ppm}$, respectively), appear upfield of the corresponding signals for 7 ( $\delta 3.81$ and $2.56 \mathrm{ppm}$, respectively). These relative chemical shifts are quite characteristic of diastereomeric dihydropyrones with an $\alpha$-alkoxy group. ${ }^{13}$ Cyclocondensation of $\mathbf{4}$ with $\mathbf{5}$ in the presence of $\mathrm{MgBr}_{2}$, followed by work-up with TFA gave only dihydropyrone (+)-6. The $S$ configuration at C18 
(ambruticin numbering) of $\mathbf{6}$ is the result of approach of the diene in an exo sense on the less hindered face of the $\mathrm{Mg}^{2+}$ chelated form of optically active aldehyde 4 .

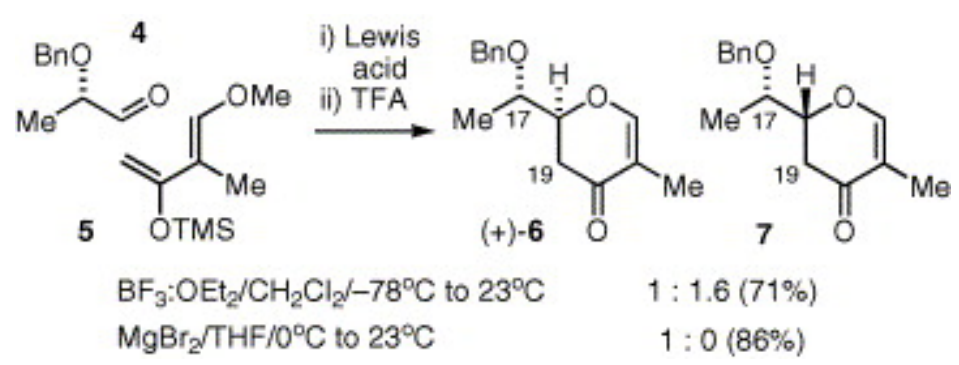

Scheme 2.

Reduction of 6 gave the pseudoglycal (+)-8 as a single diastereomer (Scheme 3). We $\mathrm{Wa}^{8 \mathrm{a}}$ and others ${ }^{14}$ have reported that the reaction of glycals with trialkylaluminium reagents is useful for the preparation of $C$-alkyl glycosides. To this end, treatment of pseudoglycal $\mathbf{8}$ with the weak nucleophile triethylaluminium, in the presence of boron trifluoride etherate, gave a mixture of trans- and cis-dihydropyrans (8:1 ratio). The major product arises via axial attack of the weak nucleophile on the cyclic oxonium ion generated by ionization of 8 . The pure trans-isomer, (-)-9, was obtained in good yield after column chromatography. Removal of the benzyl protecting group, followed by oxidation gave $(-)-11 .{ }^{15}$ Base-catalyzed epimerization of the trans-ketone, in benzene, gave a separable mixture of (-)-11 and (+)-3 (1:2 ratio). ${ }^{16}$ Two equilibration/separation cycles gave pure (+)-3 in $83 \%$ combined yield. The NMR spectral data obtained for $\mathbf{3}$ was identical with that previously reported. $^{5}$

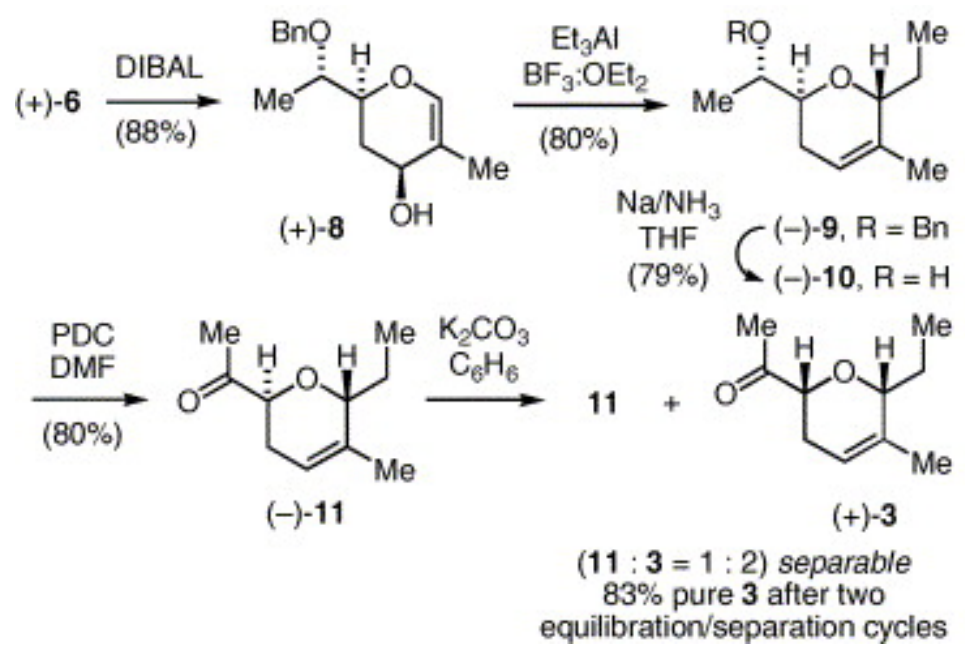

Scheme 3.

In summary, the synthesis of the dihydropyranyl segment (3), common to ambruticin and the jerangolids, from optically active aldehyde 4, was accomplished in six steps (31.7\% overall yield). The length and yield of our synthetic route is competitive with that reported by Martin and co-workers. ${ }^{5}$

\section{Acknowledgements}

Partial financial support for this research was provided by the Department of Education (P200A000228), and the Marquette University Graduate School Committee on Research. High resolution mass spectral data were obtained at the Washington University Resource for Mass Spectrometry. 


\section{References and notes}

1 D.T. Connor, R.C. Greenough, M. von Strandtmann, J. Org. Chem., 42 (1977), pp. 3664-3669

2 K. Gerth, P. Washausen, G. Höftle, H. Irschik, H. Reichenbach, J. Antibiot., 49 (1996), pp. 71-75

3 (a) For other synthetic studies of ambruticin, see:

N.J. Barnes, A.H. Davidson, L.R. Hughes, G. Procter, V. Rajcoomar, Tetrahedron Lett., 22 (1981), pp. 1751-1754 (b) N.J. Barnes, A.H. Davidson, L.R. Hughes, G. Procter, J. Chem. Soc., Chem. Commun. (1985), pp. 1292-1294 (c) G. Proctor, A.T. Russell, P.J. Murphy, P.J. Tan, A.N. Mather, Tetrahedron, 44 (1988), pp. 3953-3973 (d) A.H. Davidson, N. Eggleton, I.H. Wallace, J. Chem. Soc., Chem. Commun. (1991), pp. 378-380 (e) I.E. Marko, D.J. Bayston, Tetrahedron, 50 (1994), pp. $7141-7156$ (f) I.E. Marko, D.J. Bayston, Synthesis (1996), pp. 297-304 (g) H. Wakamatsu, N. Isono, M. Mori, J. Org. Chem., 62 (1997), pp. 8917-8922 (h) P. Varelis, B.L. Johnson, Aust. J. Chem., 59 (1997), pp. 43-51 (i) V. Michelet, K. Adiey, B. Bulic, J.-P. Genet, G. Dujardin, S. Rossignol, E. Brown, L. Toupet, Eur. J. Org. Chem. (1999), pp. 2885-2892 (j) J. Yin, I. Llorente, L.A. Villanueva, L.S. Liebeskind, J. Am. Chem. Soc., 122 (2000), pp. 10458-10459 (k) I.E. Marko, T. Kumamoto, T. Giard, Adv. Synth. Catal. (2002), pp. 1063-1067 (I) V. Michelet, K. Adiey, S. Tanier, G. Dujardin, J.-P. Genet, Eur. J. Org. Chem. (2003), pp. 2947-2958

4 (a) A.S. Kende, J.S. Mendoza, Y. Fujii, J. Am. Chem. Soc., 112 (1990), pp. 9645-9646 (b)

A.S. Kende, J.S. Mendoza, Y. Fujii, Tetrahedron, 49 (1993), pp. 8015-8038

5 (a) T.A. Kirkland, J. Colucci, L.S. Geraci, M.A. Marx, M. Schneider, D.E. Kaelin Jr., S.F. Martin, J. Am. Chem. Soc., 123 (2001), p. 12432 (b)

S.M. Beberich, R.J. Cherney, J. Colucci, C. Courillon, L.S. Geraci, T.A. Kirkland, M.A. Marx, M. Schneider, S. F. Martin, Tetrahedron, 59 (2003), pp. 6819-6832

6 E. Lee, S.J. Choi, H. Kim, H.O. Han, Y.K. Kim, S.J. Min, S.H. Son, S.M. Lim, W.S. Jang, Angew. Chem., Int. Ed., 41 (2002), pp. 176-177

7 P. Liu, E.N. Jacobsen, J. Am. Chem. Soc., 123 (2001), pp. 10772-10773

8 (a) J.M. Lukesh, W.A. Donaldson, Tetrahedron: Asymmetry, 14 (2003), pp. 757-762 (b) P.B. Greer, W.A. Donaldson, Tetrahedron, 58 (2002), pp. 6009-6018 (c) L. Liu, W.A. Donaldson, Synlett (1996), pp. 103-104

9 (a) S. Danishefsky, M.T. Bilodeau, Angew. Chem., Int. Ed. Engl., 35 (1996), pp. 1380-1419 (b) S.J. Danishefsky, Aldrichim. Acta, 19 (1986), pp. 59-69

10 D. Enders, S. von Berg, B. Jandeleit, Org. Synth., 78 (2002), pp. 177-188

11 S. Danishefsky, C.F. Yan, R.K. Singh, R.B. Gammill, P.M. McCurry, N. Fritsh, J. Clardy, J. Am. Chem. Soc., 101 (1979), pp. 7001-7008

12 Compound 6: ${ }^{1} \mathrm{H}$ NMR $\left(300 \mathrm{MHz}, \mathrm{CDCl}_{3}\right): \delta=7.39-7.28(\mathrm{~m}, 6 \mathrm{H}), 4.70(\mathrm{~d}, J=11.7 \mathrm{~Hz}, 1 \mathrm{H}), 4.53(\mathrm{~d}, J=11.7 \mathrm{~Hz}$, $1 \mathrm{H}$ ), 4.34 (ddd, $J=14.7,3.8,3.6 \mathrm{~Hz}, 1 \mathrm{H}), 3.69$ (qd, $J=6.5,4.7 \mathrm{~Hz}, 1 \mathrm{H}), 2.79$ (dd, $J=16.4,14.7 \mathrm{~Hz}, 1 \mathrm{H}$ ), $2.36(\mathrm{dd}, J=16.7,3.2 \mathrm{~Hz}, 1 \mathrm{H}), 1.68(\mathrm{~d}, J=1.2 \mathrm{~Hz}, 3 \mathrm{H}), 1.30(\mathrm{~d}, J=6.5 \mathrm{~Hz}, 3 \mathrm{H})$. Compound 7: ${ }^{1} \mathrm{H}$ NMR $\left(300 \mathrm{MHz}, \mathrm{CDCl}_{3}\right) \delta 7.39-7.27(\mathrm{~m}, 6 \mathrm{H}), 4.67(\mathrm{~d}, J=11.7 \mathrm{~Hz}, 1 \mathrm{H}), 4.59(\mathrm{~d}, J=12.0 \mathrm{~Hz}, 1 \mathrm{H}), 4.33$ (ddd, $J=14.4,3.8,3.8 \mathrm{~Hz}, 1 \mathrm{H}$ ), $3.81(\mathrm{qd}, J=6.5,4.1 \mathrm{~Hz}, 1 \mathrm{H}), 2.68(\mathrm{dd}, J=16.7,14.4 \mathrm{~Hz}, 1 \mathrm{H}$ ), 2.56 (dd, $J=16.7,3.5 \mathrm{~Hz}, 1 \mathrm{H}$ ), 1.70 (d, $J=1.2 \mathrm{~Hz}, 3 \mathrm{H}$ ), 1.27 (d, $J=6.5 \mathrm{~Hz}, 3 \mathrm{H}$ ).

13 S.J. Danishefsky, W.H. Pearson, D.F. Harvey, C.J. Maring, J.P. Springer, J. Am. Chem. Soc., 107 (1985), pp. 1256-1268

14 (a) K. Maruoka, K. Nonoshita, T. Itoh, H. Yamamoto, Chem. Lett. (1987), pp. 2215-2216 (b) P.P. Deshpande, K.N. Price, D.C. Baker, J. Org. Chem., 61 (1996), pp. 455-458

15 Compound 11: [ $\alpha$ ]D23 -129.2 (c $0.3320, \mathrm{CHCl}_{3}$ ); IR (neat): 2967, 2934, 2876, 1717, 1453, 1355, 1120, 1053, $924 \mathrm{~cm}^{-1} ;{ }^{1} \mathrm{H} \mathrm{NMR}\left(300 \mathrm{MHz}, \mathrm{CDCl}_{3}\right): \delta=5.49$ (ddd, $\left.J=6.2,3.5,1.8 \mathrm{~Hz}, 1 \mathrm{H}\right), 4.06(\mathrm{dd}, J=7.9,5.9 \mathrm{~Hz}, 1 \mathrm{H})$, $4.00(\mathrm{br} \mathrm{d}, J=9.7 \mathrm{~Hz}, 1 \mathrm{H}), 2.24(\mathrm{~s}, 3 \mathrm{H}), 2.22-2.14(\mathrm{~m}, 2 \mathrm{H}), 1.70(\mathrm{~s}, 3 \mathrm{H}), 1.74-1.49(\mathrm{~m}, 2 \mathrm{H}), 1.02$ 
(t, $J=7.3 \mathrm{~Hz}, 3 \mathrm{H}) ;{ }^{13} \mathrm{C} \mathrm{NMR}\left(75 \mathrm{MHz}, \mathrm{CDCl}_{3}\right): \delta=209.6,136.0,118.1,78.1,73.3,26.8,26.2,24.7,20.1$, 10.7; El-HRMS $m / z$ 168.1150 (calcd for $\mathrm{C}_{10} \mathrm{H}_{16} \mathrm{O}_{2} \mathrm{~m} / \mathrm{z}$ 168.1136). Compound 3: [ $\alpha$ ]D23 +172 (c 0.248, $\mathrm{CHCl}_{3}$ ); IR (neat): 2966, 2936, 2879, 1721, 1435, 1352, 1229, 1116, 1058, $927 \mathrm{~cm}^{-1}$; ${ }^{1} \mathrm{H}$ NMR (300 MHz, $\left.\mathrm{CDCl}_{3}\right): \delta=5.60-5.33(\mathrm{~m}, 1 \mathrm{H}), 4.13-4.05(\mathrm{~m}, 1 \mathrm{H}), 3.92(\mathrm{dd}, J=10.4,4.4 \mathrm{~Hz}, 1 \mathrm{H}), 2.25(\mathrm{~s}, 3 \mathrm{H}), 2.21-2.00$ $(\mathrm{m}, 2 \mathrm{H}), 1.81$ (ddq, $J=14.9,10.9,3.5 \mathrm{~Hz}, 1 \mathrm{H}), 1.60$ (ddd, $J=2.4,2.4,1.4 \mathrm{~Hz}, 3 \mathrm{H}), 1.54$ (ddq, $J=14.1,7.0$, $7.0 \mathrm{~Hz}, 1 \mathrm{H}), 0.95(\mathrm{t}, J=7.3 \mathrm{~Hz}, 3 \mathrm{H}) ;{ }^{13} \mathrm{C} \mathrm{NMR}\left(75 \mathrm{MHz}, \mathrm{CDCl}_{3}\right): \delta=210.0,135.7,119.7,79.0,78.5,27.6$, 26.1, 25.9, 19.2, 9.0.

16 Notably, ab initio calculations (6-31G* basis set) of the two stereoisomers indicated that the cis-isomer (3) is $0.77 \mathrm{kcal} \mathrm{mol}^{-1}$ lower in energy compared to the trans-isomer (11). 